\title{
Peran Pendidikan Agama Kristen dalam Kemajemukan di Indonesia
}

\author{
Alfeni Tatipang ${ }^{1}$, Ribka Baransano2 ${ }^{2}$ Melkius Ayok ${ }^{3}$, Hendrika Wakris ${ }^{4}$, Jufri Indow ${ }^{5}$ \\ 1,2,3,4,5Sekolah Tinggi Teologi Erikson-Tritt, Manokwari \\ 19alfenitatipang@gmail.com, ${ }^{2}$ ribka@stteriksontritt.ac.id, ${ }^{3}$ melkius@stteriksontritt.ac.id, \\ hㅡㄹendrikawakris@gmail.com,5jufriindou@gmail.com
}

\begin{abstract}
The diversity of Indonesia is not only a strength of the nation but also an identity of the Indonesian nation. This plurality can be seen in the differences in religion, race, and language, in the Indonesian nation. The role of Christian religious education is a very important part, for example, Indonesia, which is diverse in religion, is very vulnerable to inter-religious conflicts. Christian Religious Education exists to be a means of unifying amidst the plurality of religions, racial and linguistic pluralism in this nation. In addition to being a unifier of the nation, Christian Religious Education should be present to participate in improving the quality of Indonesian people in terms of morals and ethics in order to create peace in national solidarity.
\end{abstract}

Keywords: Christian education; diversity; plurality; pluralism

\begin{abstract}
Abstrak: Keragaman Indonesia bukan hanya sekedar menjadi sebuah kekuatan bangsa tetapi juga menjadi sebuah identitas Bangsa Indonesia. Kemajemukan tersebut dapat dilihat pada perbedaan beragama, ras, dan bahasa, dalam bangsa Indonesia. Peran Pendidikan Agama Kristen menjadi bagian yang sangat penting, misalnya Indonesia yang beragam Agama sangat rentan dengan konlik antar beragama. Pendidikan Agama Kristen hadir untuk menjadi sarana untuk pemersatu ditengah kemajemukan Agama, kemajemukan ras dan bahasa dalam bangsa ini. Selain menjadi pemersatu bangsa hendaknya Pendidikan Agama Kristen hadir untuk berperan serta dalan meningkatkan kualitas manusia Indonesia dalam hal moral dan etika agar dapat menciptakan kedamaian dalam solidaritas bangsa.
\end{abstract}

Kata kunci: keragaman; kemajemukan; pendidikan agama Kristen; pluralisme

\section{PENDAHULUAN}

Indonesia merupakan negara kepulauan yang terdiri dari banyak pulau dengan memiliki bermacam-macam keberagaman yang khas, diantaranya suku, budaya, bahasa, dan agama. Sehingga Indonesia sangat terkenal dengan semboyang Bhineka Tunggal Ika yang artinya berbeda-beda tetapi satu. Dalam konteks kemajemukan yang telah menjadi jati diri bangsa Indonesia, maka kesatuan dan kerukunan menjadi kata kunci yang penting bagi kelangsungan Negara Kesatuan Republik Indonesia. Sehingga, dalam keberagaman dan kemajemukan yang ada di Indonesia, peran agama sangatlah penting untuk menjaga perdamaian dan toleransi untuk mampu menghargai serta dapat hidup berdampingan di tengah masyarakat majemuk tersebut. Peranan dan partisipasi Pendidikan Agama Kristen dalam kehidupan masyarakat majemuk adalah peranan edukatif, sosial dan spiritual. ${ }^{1}$ Pada prinsip-

${ }^{1}$ Katalog: Djoys Anneke Rantung, Pendidikan Agama Kristen dalam Kehidupan Masyarakat Majemuk, Djoys Anneke Rantung Cet. 1, Yogyakarta: Lintang Rasi Aksara Books, 2017. 
nya PAK adalah wadah pembelajaran yang efektif dalam menanamkan nilai-nilai Kristiani bagi setiap orang Kristen untuk dapat hidup di tengah masyarakat majemuk, serta mampu memberikan komitmen iman yang kuat kepada setiap orang percaya di tengah keberagaman yang ada di Indonesia. Oleh karena itu, peranan PAK di tengah masyarakat Indonesia yang majemuk sangatlah penting, untuk menjadi landasan dan prinsip hidup orang percaya untuk tetap taat dan setia kepada Tuhan sesuai dengan kebenaran yang ada dalam Alkitab.

Pendidikan Agama Kristen yang disingkat dengan PAK, sudah umum dikenal dalam dunia ilmu Theologia. Secara umum PAK merupakan pendidikan yang secara khusus mengajarkan prinsip-prinsip kebenaran Firman Tuhan kepada setiap orang Kristen agar hidup sesuai dengan Firman Tuhan. Pendidikan Agama Kristen juga dapat didefinisikan sebagai pendidikan yang berisi ajaran-ajaran Kekristenan, dengan menekankan ketiga aspek pendidikan, yaitu pengetahuan (Kognitif), sikap dan nilai-nilai (Afektif), dan keterampilan (Psikomotor) yang berdasarkan iman Kristen. ${ }^{2}$

Pendidikan Agama Kristen pada hakekatnya mengajarkan setiap orang Kristen untuk mengenal Tuhan Yesus dengan dasar iman yang benar berdasarkan Alkitab. Sebab Pendidikan Agama Kristen dapat mengimplementasikan Firman Tuhan menjadi bagian hidup setiap orang dan komunitas masyarakat beragama Kristen di dalam seluruh dimensi kehidupan mereka. Dalam tingkatan tertentu, Pendidikan Agama Kristen bisa diatur sebagai media penginjilan dan menjadikan semua orang sebagai Kristen yang matang dan dewasa secara spiritual. ${ }^{3}$ Pendidikan yang berdasarkan Firman Allah, yang diperuntukkan bagi semua kalangan orang Kristen, baik melalui pendidikan formal maupun non formal, dengan berpusat kepada pemberitaan Kristus Yesus sebagai Tuhan dan Juruselamat melalui kebergantungan akan kuasa Roh Kudus untuk membimbing orang kepada pengenalan akan Kristus secara pribadi, serta sebagai nilai-nilai, norma dan prinsip-prinsip yang harus dilakukan sebagai orang Kristen dalam kehidupannya sehari-hari sesuai dengan standar kebenaran Alkitab

\section{METODE PENELITIAN}

Purwanto menjelaskan bahwa dalam kehidupan bergereja diperlukan sebuah penelitian yang akan menolong untuk hidup bermasyarakta. ${ }^{4}$ Penulis menggunakan metode ini karena topik yang penulis bahas adalah berkaitan dengan kehidupan masyarakat dan gereja. Penulis juga melakukan penelitian terhadap beberapa sumber yang relevan untuk menjadi sumber utama dalam penelitian ini. Penulis juga menggunakan penelitian deskriptif kualitatif yang mempelajari masalah-masalah

\footnotetext{
${ }^{2}$ Hardi Budiyana, Dasar-dasar Pendidikan Agama Kristen, (Yogyakarta: ANDI, 2011), 4.

${ }^{3}$ Elia Tambunan, Pendidikan Agama Kristen : Handbook untuk Pendidikan Tinggi, (Yogyakarta: IllumiNation, 2013), 45-46

${ }^{4}$ Lisa Karyawati, Konsep Pembelajaran Pendidikan Agama Kristen dalam Masyarakat Majemuk, Veritas Lux Mea (Jurnal Teologi dan Pendidikan Kristen) Vol. 1, No. 1 (2019): 23-29; Konsep Pembelajaran Pendidikan Agama Kristen dalam Masyarakat Majemuk | Karyawati | Veritas Lux Mea (Jurnal Teologi dan Pendidikan Kristen) (sttkn.ac.id)
} 
yang ada. Penelitian deskriptif kualitatif ini bertujuan untuk mendeskripsikan apaapa yang saat ini berlaku. Di dalamnya terdapat upaya mendeskripsikan, mencatat, analisis dan menginterpretasikan kondisi yang sekarang ini terjadi atau ada. Dengan kata lain penelitian deskriptif kualitatif ini bertujuan untuk memperoleh informasiinformasi mengenai keadaan yang ada. ${ }^{5}$

\section{HASIL PEMBAHASAN PEMBAHASAN}

\section{Peran PAK dalam Kemajemukan di Indonesia PAK Membawa kepada Keterbukaan}

Peran Pendidikan Agama Kristen harus mampu membawa setiap orang pada keterbukaan. Maksudnya sikap iman bukanlah intropert tapi ekstropert, dengan kata lain bahwa iman Kristen siap dilihat dan diselidiki. Iman Kristen justru hidup jika diaplikasikan dalam perbuatan-perbuatan. ${ }^{6}$ Keterbukaan akan menghindarkan diri dari menjelek-jelekan agama lain, tetapi melihat secara positif bahwa dalam agama lain pun terdapat ajaran-ajaran yang baik.

Sikap keterbukaan ini, mampu membawa setiap orang Kristen untuk dapat melihat orang lain atau agama-agama lain sebagai saingan atau musuh, tetapi sebagai sahabat dalam kehidupan sehari-hari. Keterbukaan memungkinkan orangorang Kristen dapat menjadi berkat bagi sesamanya serta mampu memiliki sikap toleransi antar sesama yang berbeda keyakinan. Prinsip keterbukaan ini diakui pula oleh Nainggolan, yang mengatakan bahwa Pendidikan Agama Kristen haruslah dapat memberi pengajaran iman yang menuju keterbukaan dan bukan ketertutupan apalagi fanatisme keagamaan, prinsip pengajaran Kristen adalah bahawa setiap orang beriman harus fanatik akan imannya tapi tidak boleh fanatisme, karena fanatisme adalahs salah satu sikap buruk dalam keagamaan. ${ }^{7}$ Dengan kata lain bahwa setiap orang Kristen bisa menghargai akan kepercayaan agama lain namun tetap konsisten dan memiliki komitmen iman yang tinggi kepada Kristus. Sikap keterbukaan ini sangat penting dalam konteks masyarakat majemuk yang ada di Indonesia, sikap ini juga dikenal dengan sikap Inklusif, konsep lingkungan inklusif, berarti semua orang yang tinggal, berada dan beraktivitas dalam lingkungan keluarga, sekolah ataupun masyarakat merasa aman dan nyaman mendapatkan hak dan melaksanakan kewajibannya.

Lingkungan inklusif adalah lingkungan sosial masyarakat yang terbuka, ramah, meniadakan hambatan dan menyenangkan karena setiap warga masyarakat tanpa terkecuali saling menghargai dan merangkul setiap perbedaan. ${ }^{8}$ Sehingga pentingnya PAK hadir untuk membawa sikap keterbukaan di tengah-tengah masyarakat majemuk di indonesia yang harus menjunjung tinggi toleransi umat beragama. Oleh karena itu, PAK harus membebaskan orang-orang Kristen dari sekat-sekat pri-

\footnotetext{
${ }^{5}$ Mardalis, Metode Penelitian Suatu Pendekatan Proposal, (Jakarta: Bumi Aksara, 1999), 26

${ }^{6}$ John Nainggolan, Pendidikan Agama Kristen, (Bandung: Bina Media Informasi, 2009), 25.

${ }^{7}$ John Nainggolan, Pendidikan Agama Kristen, (Bandung: Bina Media Informasi, 2009), 67.

${ }^{8} \mathrm{http}: / /$ yannyhya.blogspot.com/2014/05/pak-dalam-masyarakat-majemuk.html
} 
mordialisme, agar jangan sampai PAK melemahkan kemampuan bertoleransi dan menguatkan fanatisme. ${ }^{9}$

Kehadiran pendidikan agama Kristen di tengah-tengah masyarakat majemuk sangatlah penting, dengan tujuan agar orang-orang percaya dapat hidup dan mengaplikasikan imannya dalam kehidupan sehari-hari. Setiap pengikut Kristus tidak boleh tertutup atau menghindarkan diri dari dunia sekitarnya, melainkan kehidupan orang percaya haruslah menjadi berkat dan garam di tengah-tengah masyarakat majemuk melalui pendidikan agama Kristen. Oleh karena itu, dengan kata lain bahwa agama memiliki peranan besar dalam rangkan pembangunan nasional sebagai faktor motivatif, kreatif, inovatif, integratif (individual, sosial), sublimatif (penghayatan), dan sumber inspirasi sosio budaya Indonesia. ${ }^{10}$

Sehingga melalui pendidikan agama Kristen, orang Kristen mampu memiliki sikap keterbukaan yang mendorong sikap toleran dan penghargaan atas perbedaan pandangan umat dengan berbagai keyakinan yang ada di Indonesia.

\section{PAK Membawa Kepada Kemandirian Iman}

Kemandirian merupakan suatu keadaan berdiri sendiri dan tanpa bergantung pda orang lain. Kemandirian berarti memiliki kepribadian yang dapat berdiri sendiri dalam hubungan secara langsung dengan Kristus sebagai sumber segalanya. 11 Sehingga dalam berbagai konteks kemajemukan masyarakat yang ada di Indonesia, dalam berbagai bentuk perbedaan yang ada, PAK harus diarahkan kepada kemandirian iman. Tidak dapat dipungkiri bahwa perbedaan-perbedaan dalam masyarakat baik dalam hal agama maupun etinis akan saling bersentuhan. Sentuhansentuhan itu amat kuat dan jika tidak memiliki kemandirian iman maka akan kalah. Hal ini bisa dilihat pada keadaan akhir-akhir ini, perpindahan agama telah semakin lazim di tengah masyarakat. Hal itu terjadi karena sentuhan-sentuhan dalam heterogenitas agama tidak bisa dihindarkan.

Oleh karena itu, PAK haruslah menjadi salah satu usaha pembentukan kemandirian iman, bahwa setiap orang Kristen harus mampu memiliki ketetapan iman maupun ketetapan hati meskipun di lingkungan yang amat berbeda. ${ }^{12}$ Sehingga pentingnya peran PAK dalam konteks masyarakat majemuk di Indonesia. Karena Pendidikan Agama Kristen sejatinya adalah sebuah wadah pembelajaran yang efektif dalam menanamkan nilai-nilai Kristiani bagi setiap orang percaya, PAK mengajarkan kepercayaan, ketataan dan komitmen iman. Iman yang hidup adalah iman yang dapat dikomunikasi dan mengubah serta berdialog dengan konteks ${ }^{13}$

Oleh karena itu, melalui kemandirian iman, setiap orang Kristen mampu memiliki kemampuan untuk menempatkan dirinya di tengah-tengah masyarakat

\footnotetext{
9 Ibid.,

${ }^{10}$ R.M. Drie S. Brotosudarmo, Pendidikan Agama Kristen untuk Perguruan Tinggi, (Yogyakarta: ANDI, 2008), 15.

${ }^{11}$ Yeheskielsjioen89-wordpress-com.cdn.ampproject.org.

12 John Nainggolan, Pendidikan Agama Kristen, (Bandung: Bina Media Informasi, 2009), 24.

${ }^{13}$ Katalog: Djoys Anneke Rantung, Pendidikan Agama Kristen dalam Kehidupan Masyarakat Majemuk, Cet. 1, Yogyakarta: Lintang Rasi Aksara Books, 2017.129.
} 
majemuk yang memiliki keyakinan yang berbeda tanpa harus terpengaruh dengan kepercayaan dan keyakinan agama lain, namun tetap konsisten dan menjaga kemandirian imannya serta mampu menolak segala tren-tren kehidupan yang bertentangan dengan nilai-nilai iman kekristenan yang dimilikinya.

Dalam situasi masyarakat Indonesia yang majemuk, merupakan sesuatu yang tidak dapat dihindari dalam realita kehidupan orang Kristen. Sehingga Pendidikan Agama Kristen harus memainkan peranan penting bagi generasi mudah maupun setiap orang percaya yang di didik di gereja maupun di sekolah. Gereja tidak dapat mendidik setiap orang percaya dengan mempertentangkan terus-menerus perbedaan di antara agama-agama dan budaya yang ada melainkan PAK hadir untuk memberikan pemahaman untuk dapat hidup berdampingan di tengah masyarakat Indonesia yang majemuk. Sehingga PAK memainkan perananya untuk setiap orang percaya untuk mampu memiliki kemandirian iman untuk terus setia dan memiliki iman yang kokoh kepada Kristus.

Karena iman merupakan fondasi dasar dari setiap kehidupan kekristenan. Tanpa iman, tidak mungkin setiap orang percaya berkenan kepada Allah. Sehingga kemandirian iman atau kehidupan iman itu sangatlah penting, karena segala sesuatu dalam kehidupan spiritual berakar dan didasari oleh iman. Setiap orang yang sudah meneriman Yesus Kristus sebagai Tuhan dan Juruselamatnya secara pribadi perlu memupuk imannya serta memiliki kemandirian iman yang tidak mudah dipengaruhi oleh apapun yang bertentanngan dengan iman percayanya kepada Kristus.

Oleh karena itu, pendidikan agama Kristen dilakukan untuk menciptakan persekutuan dengan Allah dan mewujudkan pertumbuhan iman Kristen, sebab iman Kristen harus dipahami secara utuh dan menyeluruh dalam arti seluruh kehidupan Kristiani. Dianggap utuh dan menyeluruh karena mencakup pengetahuan, afeksi dan tindakan, sebagaimana yang dipaparkan oleh Budiyana dalam bukunya Dasar-dasar Pendidikan Agama, bahwa Iman Kristen dalam dimensi kognitif mencakup pengetahuan dan pengertian akan Tuhan dan kehendak-Nya, yakni seperti yang dinyatakan dalam firman-Nya, tetapi juga sebagaimana dirumuskan dalam berbagai doktrin dan ajaran gereja yang sudah akumulatif. Sementara iman Kristen dalam dimensi afektif, mencakup hubungan pribadi dengan Tuhan, penyerhan diri, komitmen Kristiani, kasih dan sikap hormat, kagum terhadap Tuhan dan ciptaan-Nya, serta respon terhadap seluruh kehidupan spritualitasnya. Sedangkan Iman Kristen dalam dimensi tindakan adalah pelayanan terhadap dunia dalam kasih sebagai respon terhadap kerajaan Allah. ${ }^{14}$

Berdasarkan ketiga dimensi iman yang dikemukakan oleh Budiyana di atas, merupakan sikap yang harus ada pada diri orang percaya yang tinggal di tengatengah masyarakat majemuk agar mampu mencapai kemandirian iman dengan

Memiliki kepercayaan iman yang tangguh di dalam Tuhan. Salah satu peranan PAK di tengah masyarakat Indonesia yang majemuk adalah untuk menjaga kemurni-

${ }^{14}$ Hardi Budiyana, Dasar-dasar Pendidikan Agama Kristen, (Yogyakarta: ANDI, 2011), 15. 
an dan kemandirian iman orang percaya, mengarahkannya kepada karya keselamatan Kristus melalui pengenalan yang benar akan Allah, serta membangun generasi yang takut akan Allah dan percaya kepada janji firman-Nya.

Memang dalam situasi dan kondisi saat ini, pergumulan gereja selalu berkembang dari zaman ke zaman, dan PAK ditantang untuk mampu mengajarkan Firman Tuhan bagi warga jemaat terkait peranan spiritualnya. Robert Bohlke mencontohkan kondisi yang dialami pada jaman Gereja purba, bahwa; "penyelenggaraan PAK merupakan usaha untuk bergumul dengan kebudayaan yang nilai-nilainya bermusuhan terhadapnya dalam lingkungan luas."15 Sehingga pentingnya peranan PAK untuk mampu menguatkan iman orang percaya masa kini, agar mampu memiliki kemandirian iman dan mampu bertahan di tengah situasi dan tantangan yang ada di sekelilingnya di tengah-tengah masyarakat Indonesia yang pluralistik.

Melalui pendidikan agama Kristen, orang Kristen mampu melihat secara tajam kekhasan iman Kristen dan sekaligus belajar dari cara pandang iman lain, maksudnya ialah membangun nara didik atau para pengikut Kristus untuk memiliki indentitas dan komitmen yang jelas tentang imannya dan sekaligus membangun relasi dengan orang yang berkepercayaan lain dan berinteraksis secara positif tanpa saling mengorbankan. ${ }^{16}$ Sebab itulah PAK hadir untuk berperan mendidik setiap orang Kristen untuk mengerti imannya secara sadar dan memiliki kemandirian iman yaitu, dengan mampu memiliki komitmen iman yang kuat dalam Kristus serta dapat melihat aliran atau agama lain secara obyektif tanpa harus terpengaruh.

\section{PAK Sebagai Sarana Penginjilan}

Peranan PAK di tengah-tengah masyarakat Indonesia yang majemuk, bukan hanya mampu membawa setiap orang Kristen memiliki sikap terbuka terhadap keyakinan orang lain dan membawa kepada kemandirian iman, melainkan Pendidikan Agama Kristen juga merupakan sarana penginjilan. Sebagaimana visi dan misi dari pendidikan agama Kristen itu sendiri yang dipaparkan oleh Brotosudarmo bahwa semua orang perlu diselamatkan melalui Yesus Kristus serta menyatakan Kabar Baik bagi umat manusia untuk membebaskannya dari perbuatan dosa. ${ }^{17} \mathrm{Hal}$ ini juga diakui oleh Homrighausen dan Enklaar yang mengatakan bahwa Gereja juga dipanggi untuk menyampaikan Firman itu kepada sekalian orang yang telah menjauhkan diri daripadanya atau yang belum pernah bertemu Tuhan Yesus ${ }^{18}$

Mendasari akan hal di atas, bahwa sebenarnya penginjilan merupakan perintah dari Tuhan Yesus sendiri. Buktinya Allah mengutus Yesus Kristus datang ke dunia untuk menebus dosa dan manusia yang percaya kepada-Nya mendapatkan hidup yang kekal (Yoh. 3:16). Hal ini menunjukan bahwa Allah tidak menghendaki seorangpun binasa sebagaimana yang ditulis dalam 2 Petrus 3:9b: "Karena Ia menghendaki supaya jangan ada yang binasa, melainkan semua orang berbalik dan ber-

\footnotetext{
${ }^{15}$ Robert R. Bohlke, Sejarah Perkembangan,142.

${ }^{16}$ John Nainggolan, Pendidikan Agama Kristen, (Bandung: Bina Media Informasi, 2009), 59.

${ }^{17}$ R.M. Drie S. Brotosudarmo, Pendidikan Agama Kristen untuk Perguruan Tinggi, (Yogyakarta: ANDI, 2008), 16.

${ }^{18}$ Homrighausen dan Enklaar, Pendidikan Agama Kristen, (Jakarta: Gunung Mulia, 2011), 20.
} 
tobat." Oleh karena itu, Tuhan Yesus memberikan amanat (Mat. 28:18-20) kepada murid-murid-Nya supaya melaksanakan penginjilan. ${ }^{19}$ Inti dari amanat agung itu ialah "Jadikanlah semua bangsa murid-Ku". Artinya bahwa orang-orang harus dibawa kepada Kristus, sehingga mereka beriman dan menyerahkan diri kepada Dia. ${ }^{20}$

Penginjilan adalah merupakan amanat kepada gereja dan kepada orang-orang percaya dan berlangsung secara terus-menerus. Artinya melalui peran dari pendidikan agama Kristen ini, mampu membekali setiap orang percaya untuk pergi menjadikan orang lain sebagai murid Kristus sebagaimana yang telah diamanatkan oleh Yesus sendiri. Namun dalam realita atau dalam konteks keberagaman agama yang ada di Indonesia, merupakan salah satu hal yang menjadi tantangan terbesar dalam melaksanakan penginjilan. Apalagi sebagai warga negara Indonesia yang harus menjunjung tinggi toleransi umat beragama. Di tengah situasi masyarakat Indonesia yang majemuk, agama merupakan suatu yang sangat sensitif, karena jika ada gesekan sedikit terhadap agama yang satu dan yang lain, maka akan sangat cepat menimbulkan perpecahan atau konflik antara umat beragama.

Oleh karena itu, pentingnya bagi orang percaya memahami pendidikan agama Kristen dengan baik dan benar, agar dapat melaksaksanakan penginjilan bagi orangorang yang belum menerima Kristus sebagai Tuhan dan Juruselamat secara pribadi. Hal ini dibenarkan pula oleh Nainggolan, yang mengatakan bahwa Pendidikan Agama Kristen haruslah mengandung aspek penginjilan, sebab Pak tanpa penginjilan adalah mati dan menghilangkan Amanat Agung Tuhan Yesus Kristus, karena tujuan tertinggi dari PAK itu sendiri adalah membawa setiap orang kepada perjumpaan dengan Kristus, dan mengalami pertumbuhan rohani serta menghasilkan buah-buah rohani di dalam hidupnya. ${ }^{21}$ Sehingga PAK di tuntut untuk mengembangkan pendekatan yang menyeluruh, dalam memperlengkapi orang percaya sebagai pribadipribadi dalam mengembangkan keutuhannnya serta memiliki keahlian dan kecakapan untuk pergi memberitakan Injil.

Dalam menerapkan PAK sebagai sarana dalam memberitakan Injil di tengah masyarakat Indonesia yang majemuk memang bukanlah perkara yang mudah. Untuk itu pendidikan agama Kristen dalam menjalankan perananya untuk memberitakan Injil di tengah masyarakat majemuk, haruslah memiliki strategi yang tepat. Untuk pemberitaan Injil harus amat memperhatikan konteks sosial-budaya; untuk

${ }^{19}$ Susanto Dwiraharjo, “Kajian Eksegetikal Amanat Agung Menurut Matius 28 : 18-20," Jurnal Teologi Gracia Deo 1, no. 2 (2019): 56-73, http://sttbaptisjkt.ac.id/e-journal/index.php/graciadeo; Handreas Hartono, "Mengaktualisasikan Amanat Agung Matius 28 : 19-20 Dalam Konteks Era Digital," KURIOS (Jurnal Teologi dan Pendidikan Agama Kristen) 4, no. 2 (2018): 19-20, www.sttpb.ac.id/e-journal/index.php/kurios; Fransiskus Irwan Widjaja, Daniel Ginting, and Sabar Manahan Hutagalung, "Teologi Misi Sebagai Teologi Amanat Agung," THRONOS: Jurnal Teologi Kristen 1, no. 1 (2019): 17-24; Halim Wiryadinata et al., "Mission And Evangelism: African Context," KURIOS (Jurnal Teologi dan Pendidikan Agama Kristen) (Jurnal Teologi dan Pendidikan Agama Kristen) 3, no. 1 (2015): 1-11.

${ }^{20}$ John Nainggolan, Pendidikan Agama Kristen, (Bandung: Bina Media Informasi, 2009), 66.

${ }^{21}$ Ibid., 70. 
pelayanan, konteks sosial-ekonomi. ${ }^{22}$ Sehingga dengan demikian dapat diatur cara atau metode yang tepat dalam penginjilan pada setiap daerah-daerah tertentu, mengingat latar belakang Indonesia yang beranekaragam suku, bahasa, budaya dan agama.

\section{KESIMPULAN}

Pendidikan Agama Kristen merupakan pendidikan yang berdasarkan Alkitab yang berpusat pada Kristus sebagai pusat pemberitaannya dan bergantung pada kuasa Roh Kudus untuk membimbing orang pada pengenalan akan Kristus dan mampu menerima-Nya sebagai Tuhan dna Juruselamat secara pribadi yang membawa orang percaya bertumbuh pada kedewasaan penuh di dalam Kristus. Oleh karena itu, Pendidikan Agama Kristen memiliki peranan yang sangat penting di tengah-tengah masyarakat majemuk di Indonesia. Dimana peran Pendidikan Agama Kristen mampu membawa kepada keterbukaan terhadap sesama yang berbeda keyakinan mampu memiliki sikap toleransi dan menghargai pemeluk agama lain dan dapat hidup berdampingan di tengah masyarakat Indonesia yang majemuk tanpa harus terpengaruh dengan kepercayaan orang lain namun tetap memiliki kemandirian iman melalui komitmen iman yang sungguh kepada Kristus.

Selain dari pada itu, peran PAK juga sebagai sarana penginjilan untuk menyampaikan Amanat Agung Tuhan Yesus, dimana Yesus memerintahkan semua bangsa untuk menjadi murid-Nya. Oleh karena itu, peranan PAK, merupakan salah satu sarana untuk dapat memenangkan jiwa-jiwa bagi kemuliaan nama Tuhan Yesus Kristus agar orang lain juga dapat diselamatkan dan dapat meneriman Kristus sebagai Tuhan dan Juruselamat secara pribadi dan menjadi dewasa di dalam Kristus.

\section{REFERENSI}

Budiyana, Hardi. Dasar-dasar Pendidikan Agama Kristen, Yogyakarta: ANDI, 2011.

Brotosudarmo, M. Drie S., Pendidikan Agama Kristen untuk Perguruan Tinggi, Yogyakarta: ANDI, 2008.

Boehlke, Robert R. Sejarah Perkembangan Pemikiran dan Praktek PAK dari Plato sampai Ig. Layola, Jakarta: Gunung Mulia, 2002.

Dwiraharjo, Susanto. "Kajian Eksegetikal Amanat Agung Menurut Matius 28 : 18-20." Jurnal Teologi Gracia Deo 1, no. 2 (2019): 56-73. http://sttbaptisjkt.ac.id/ejournal/index.php/graciadeo.

Hartono, Handreas. "Mengaktualisasikan Amanat Agung Matius 28 : 19-20 Dalam Konteks Era Digital." KURIOS (Jurnal Teologi dan Pendidikan Agama Kristen) 4, no. 2 (2018): 19-20. www.sttpb.ac.id/e-journal/index.php/kurios.

Homrighausen, dan Enklaar. Pendidikan Agama Kristen, Jakarta: Gunung Mulia, 2011.

Nainggolan, John. Pendidikan Agama Kristen, Bandung: Bina Media Informasi, 2009.

Pramudianto, dan Martin L. Sinaga. Pergulatan dan Kontekstualisasi Pemikiran Prostestan Indonesia, Jakarta, 1999.

${ }^{22}$ Pergulatan dan Kontekstualisasi Pemikiran Prostestan Indonesia, Peny., Pramudianto dan Martin L. Sinaga, (Jakarta, 1999), 442. 
Rantung, Djoys Anneke. Pendidikan Agama Kristen dalam Kehidupan Masyarakat Majemuk, Yogyakarta: Lintang Rasi Aksara Books, 2017.

Sidjabat, Samuel b. Strategi Pendidikan Kristen, Yogyakarta: Andi Offset, 1994.

Tambunan, Elia. Pendidikan Agama Kristen: Handbook untuk Pendidikan Tinggi, Yogyakarta: IllumiNation, 2013.

Werner, Graendorf C. Introduction to Biblical Christian Education, Chicago: Moody Press, 1981.

Widjaja, Fransiskus Irwan, Daniel Ginting, and Sabar Manahan Hutagalung. "Teologi Misi Sebagai Teologi Amanat Agung.” THRONOS: Jurnal Teologi Kristen 1, no. 1 (2019): 17-24.

Wiryadinata, Halim, Sekolah Tinggi, Teologi Pelita, Bangsa Jakarta, and Ketua@sttpb Ac Id. "Mission And Evangelism: African Context." KURIOS (Jurnal Teologi dan Pendidikan Agama Kristen) (Jurnal Teologi dan Pendidikan Agama Kristen) 3, no. 1 (2015): 1-11. 